JURNAL RESPIRASI

JR

Vol. 2 No. 1 Januari 2016

\title{
Seorang Penderita dengan Retrosternal Goiter
}

\author{
Mawardi, Daniel Maranatha \\ Departemen Pulmonologi dan Ilmu Kedokteran Respirasi, Fakultas Kedokteran Universitas Airlangga/RSUD Dr. Soetomo
}

\begin{abstract}
Background: Retrosternal goiter of the thyroid gland is the inclusion of 50\% or more into the thoracic cavity. Many terms are used to describe the entry of the thyroid gland into the thoracic cavity include: substernal goiter, intrathoracic goiter, retrosternal goiter and mediastinal goitre. Case: We report the case of a woman with retrosternal goiter initially suspected as a tumor in the mediastinum. Patients present with chest pain and no visible enlargement of the thyroid gland in the neck. On examination thoracic CT scan and found an enlarged thyroid gland in the chest cavity is then performed total thyroidectomy surgery and sternotomy. Conclusion: This case illustrates retrosternal goiters should be differentiated from other mediastinal masses by appropriate work-up, while computed tomography is the most valuable technique and surgical management is mandatory.
\end{abstract}

Key words: retrosternal goiter, thyroidectomy, sternotomy

Correspondence: Mawardi, Departemen Pulmonologi dan Ilmu Kedokteran Respirasi, Fakultas Kedokteran, Universitas Airlangga/ RSUD Dr. Soetomo. Jl. Mayjen. Prof Dr. Moestopo 6-8 Surabaya 60286. E-mail: ardiemawardi_dr@yahoo.co.id

\section{PENDAHULUAN}

Goiter berasal dari bahasa Latin "tumidum gutter" yang artinya tenggorokan yang membesar. Definisi lain goiter adalah kelenjar tiroid yang membesar dua kali atau lebih dari ukuran normal atau berat nya mencapai 40 gram atau lebih. Pembesaran kelenjar tiroid dapat disebabkan oleh berbagai hal, namun penyebab yang paling umum adalah kekurangan zat yodium dalam makanan. Kekurangan zat yodium akan menyebabkan subclinical hypothyroidisme, akibat peningkatan kadar TSH kemudian terjadi hipertropi kelenjar tiroid. ${ }^{1,2}$

Pembesaran kelenjar tiroid tidak hanya terjadi pada daerah leher saja, tetapi bisa juga terjadi pembesaran kelenjar tiroid hingga mencapai rongga toraks yang disebut retrosternal goiter. Haller adalah orang yang pertama kali melaporkan kasus retrosternal goiter pada tahun 1749 . Angka kejadian retrosternal goiter berkisar antara 1-20\% dari semua kasus thyroidectomy.Retrosernal goiter lebih sering terjadi pada laki-laki, leher yang pendek dan lebar. Masuknya kelenjar tiroid ke rongga toraks di pengaruhi oleh proses menelan, tekanan negatif intratoraks, gravitasi, dan struktur anatomi disekitar kelenjar tiroid. 2,3,4
Retrosternal goiter sering tidak menimbulkan gejala apabila tidak mendesak organ sekitarnya ataupun tidak menyebabkan penyempitan dari trakhea. Pada pemeriksaan ronten toraks retrosternal goiter sering memberikan gambaran seperti tumor mediastinum, hal ini tidak jarang menyebabkan salah diagnosis. ${ }^{1,4}$

Berikut dilaporkan kasus seorang wanita dengan retrosernal goiter pada awalnya di curigai sebagai tumor mediastinum. Penderita datang dengan keluhan nyeri dada dan tidak terlihat pembesaran kelenjar tiroid pada leher. Pada pemeriksaan CT scan dan FNAB toraks didapatkan pembesaran kelenjar tiroid di rongga dada yang kemudian dilakukan operasi total thyroidectomy dan sternotomy.

\section{KASUS}

Seorang wanita berusia 56 tahun masuk Rumah Sakit dr.Soetomo dengan keluhan utama nyeri dada. Nyeri dada dirasakan sejak satu tahun hilang timbul, memberat 1 bulan terakhir. Sesak kadang-kadang, terutama setelah aktivitas berat. Batuk jarang, panas badan tidak ada,berat badan tidak turun, nafsu makan baik, tidak ada nyeri menelan. 
Suara tidak parau, tangan tidak gemetar dan jantung tidak berdebar-debar. Pasien sebelumnya dirawat di Rumah Sakit swasta di Mataram, telah diperiksa foto toraks dan CT scan dada. Kemudian dirujuk ke Surabaya untuk pemeriksaan lebih lanjut. Penderita tidak pernah mengalami keluhan serupa sebelumnya, tidak pernah sakit berat, riwayat hipertensi selama sepuluh tahun terkontrol, riwayat diabetis melitus disangkal, riwayat asma disangkal.

Penderita datang dengan keadaan umum lemah, kesadaran kompos mentis, tensi 110/70 $\mathrm{mmHg}$, nadi 98x/ menit, frekuensi napas $20 \mathrm{x} / \mathrm{menit}$, suhu aksiler $36,6^{\circ} \mathrm{C}$, saturasi $\mathrm{O}_{2} 98 \%$ dengan $\mathrm{O}_{2}$ ruangan. Pada inspeksi leher tidak terlihat perbesaran kelenjar tiroid. tetapi pada palpasi teraba kelenjar tiroid kanan dengan diameter \pm 2 sentimeter. Tidak anemis, ikterus, atau sianosis. Tidak ada pembesaran kelenjar getah bening dan peningkatan vena jugularis.

Pada regio toraks, inspeksi tidak tampak adanya kolateral, pengembangan parusimetris. Pada palpasi didapatkan fremitus raba menurun 1/3 atas paru kanan dan kiri. Perkusi redup pada 1/3 atas paru kanan dan kiri. Pada auskultasi didapatkan suara vesikuler menurun $1 / 3$ atas kedua lapang paru. Pada pemeriksaan jantung, suara jantung (S1 dan S2) tunggal, tidak didapatkan bising jantung maupun irama gallop, dan apeks kordis teraba di ICS IV parasternal kanan. Pada pemeriksaan abdomen, hepar dan lien tidak teraba membesar, tidak didapatkan massa intra abdomen atau nyeri tekan, serta bising usus dalam batas normal. Pada anggota gerak tidak ditemukan edema, jari tabuh, kelemahan anggota gerak, ataupun pembesaran kelenjar getah bening di ketiak maupun lipatan paha. Penderita membawa foto toraks ketika penderita dirawat di Rumah Sakit Risa Sentra Medika Mataram-Lombok. Pada foto toraks AP tampak pelebaran mediastinum, trakea di tengah, corakan vaskular paru normal, tidak ada infiltrat, sinus costophrenicus kanan kiri tajam, jantung tak tampak kelainan. Kesan: suspek massa mediastinum dd/aneurisma aorta. Saran: CT scan toraks dengan kontras. CT scan toraks menunjukkan tiroid kanan ukuran membesar dengan densitas inhomogen, tiroid kiri normal, tampak massa padat inhomogen, komponen cairan $(+)$ dimediastinum anterior

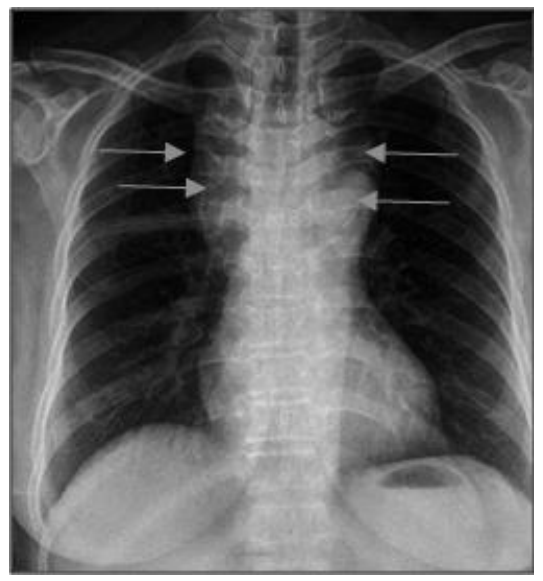

Gambar 1. Foto toraks tampak pelebaran mediastinum ditunjukan oleh tanda panah.

ukuran $\pm 8 \mathrm{~cm} \times 6 \mathrm{~cm} \times 17 \mathrm{~cm}$, batas tegas tepi licin, pada penambahan kontras tampak strong enhancement inhomogen, mendesak dan menyempitkan airway ke posterior terutama setinggi carina dan mendesak arcus aorta ke caudal, kalsifikasi intra massa (+) minimal, massa tampak berhubungan dengan tiroid kanan. Infiltrat dan corakan retikular (+) di paru kiri posterior. Efusi pleura (-), cion lesion (-), destruksi tulang $(-)$, jantung ukuran normal. Massa mediastinum superior anterior ukuran $\pm 8 \mathrm{~cm} \mathrm{x} 6$ $\mathrm{cm}$ x $17 \mathrm{~cm}$ kesan dari tiroid dekstra dd/abses paratrakhea, menyempitkan airway terutama setinggi carina. Tak tampak aneurisma aorta.

Berdasarkan pemeriksaan USG abdomen, kesan: Chronic renal disease kanan, tak tampak urolithiasis maupun hidronefrosis. Sonografi organ abdomen lainnya tak tampak kelainan. Berdasarkan pemeriksaan FNAB CT Guiding didapatkan hapusan mikroskopis tampak sebaran dan kelompok-kelompok sel epitel folikel, selnya dengan inti bulat, kecil, kromatin kasar, sitoplasma cukup, sel membentuk acini dan papillar. Latar belakang berisi bahan koloid, bahan nekrosis dan sebaran sel radang. Kesimpulan: Kesan papillary carsinoma tiroid retrosternal
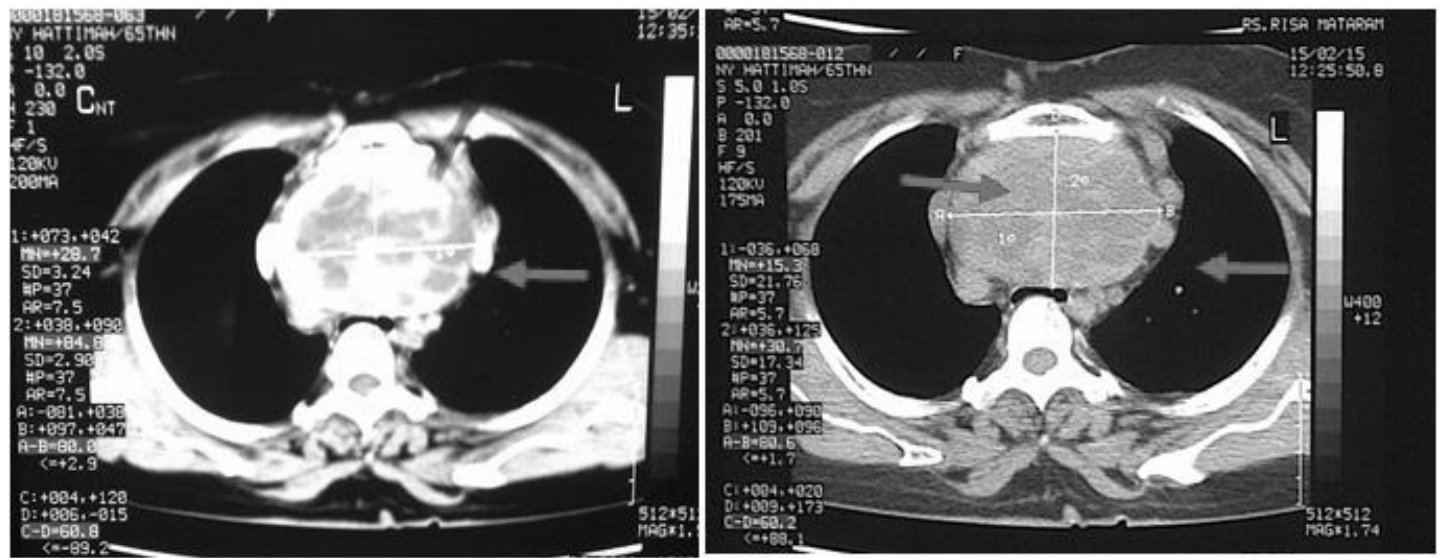

Gambar 2. CT Scan toraks, tampak massa di mediastinum anterior, ditunjukan oleh tanda panah. 


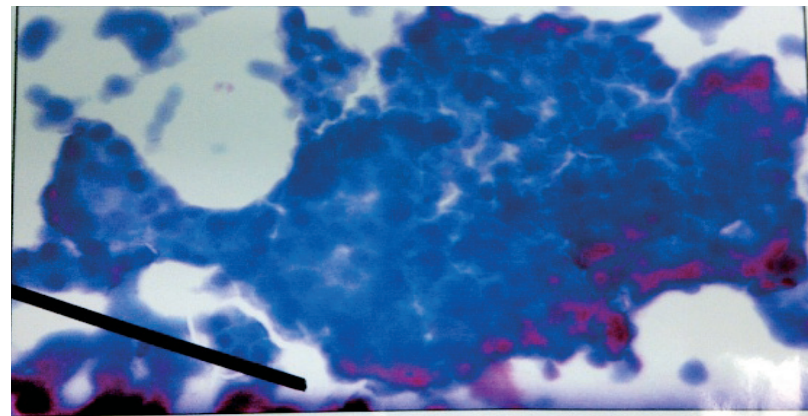

Gambar 3. Hapusan mikroskopis FNAB CT Guiding toraks.

Pasien direncanakan operasi total thyroidectomy + sternotomy. Operasi dilakukan selama kurang lebih 3 jam, setelah dilakukan pembukaan rongga dada, terlihat jaringan tiroid kanan yang tampak membesar yang berlanjut sampai rongga toraks. Tiroid kiri tampak normal. Jaringan tiroid retrosternal tampak berkapsul dengan ukuran $18 \mathrm{~cm} \mathrm{x} 7$ $\mathrm{cm} \times 4 \mathrm{~cm}$.

Penderita kembali ke ruangan bedah setelah menjalani operasi. Penderita tampak lemah dengan keluhan nyeri pada bekas luka operasi, tidak sesak namun nyeri bila menarik napas dalam dan tidak ada keluhan demam. Hemodinamik stabil, suara napas vesikular, tidak terdengar ronkhi ataupun wheezing. Terlihat drain yang terpasang pada tempat operasi, dengan produksi cairan drain $120 \mathrm{cc} / 24$ jam warna kemerahan. Penderita diberikan terapi antibiotik dan analgetik. Kadar hemoglobin setelah operasi turun menjadi 9,2 g/dl kemudian dilakukan transfusi PRC 2 kolf, kadar hemoglobin naik menjadi $11 \mathrm{~g} / \mathrm{dl}$. Albumin serum juga turun menjadi 2,2 g/dl kemudian dilakukan transfusi albumin, kadar albumin serum naik menjadi 3,74 g/dl.

Satu bulan kemudian dilakukan foto toraks evaluasi setelah operasi. Pada foto toraks tampak opasitas di mediastium yang mungkin merupakan sisa perdarahan saat operasi dan tampak benang jahitan bagian sternum.

Luka operasi tampak terawat dan tidak ada hematom. Kondisi pasien terus mengalami perbaikan setelah operasi, kemudianpasien dibolehkan rawat jalan dan kontrol ke poli bedah dan poli paru.

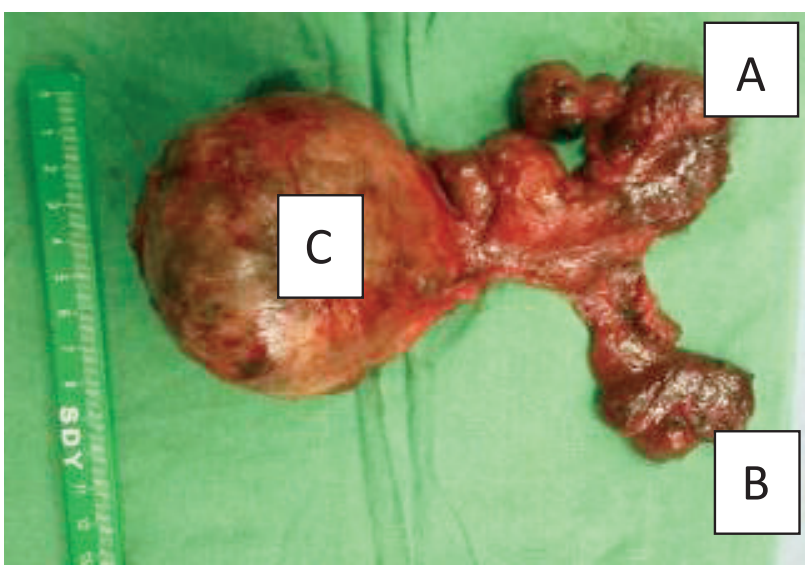

Gambar 5. Kelenjar tiroid utuh setelah dilakukan total thyroidectomy. A. Tiroid kanan B. Tiroid kiri C. Tiroid kanan yang masuk ke rongga toraks

Hasil pemeriksaan histopatologi jaringan operasi secara mikroskopis tampak potongan tiroid terdiri dari proliferasi folikel tiroid yang berukuran besar dan kecil yang dilapisi oleh selapis epitel kuboid yang berisi bahan koloid. Pada bagian lain tampak pula proliferasi folikel tiroid berukuran kecil-kecil yang tersusun padat dilapisi selapis epitel kubiod, kromatin halus. Tumor tidak menembus kapsul. Tidak tampak proses spesifik ataupun tanda-tanda keganasan. Kesimpulan: Follicular adenoma disertai adenomatous goiter.

Hasil FNAB CT guiding toraks pre-operasi mengesankan keganasan (papillary carsinoma thyroid retrosternal). Berdasarkan hasil histologi jaringan setelah operasi yang menyimpulkan adenomatous goiter dan tidak ada keganasan dan maka diagnosa akhir pasien ini adalah retrosternal goiter.

Selama rawat jalan penderita hanya mengalami keluhan ringan berupa nyeri dada bekas tempat operasi. Satu minggu kemudian penderita pulang ke pulau Sumbawa Nusa Tenggara Barat dan melanjutkan pengobatan rawat jalan di Sumbawa.
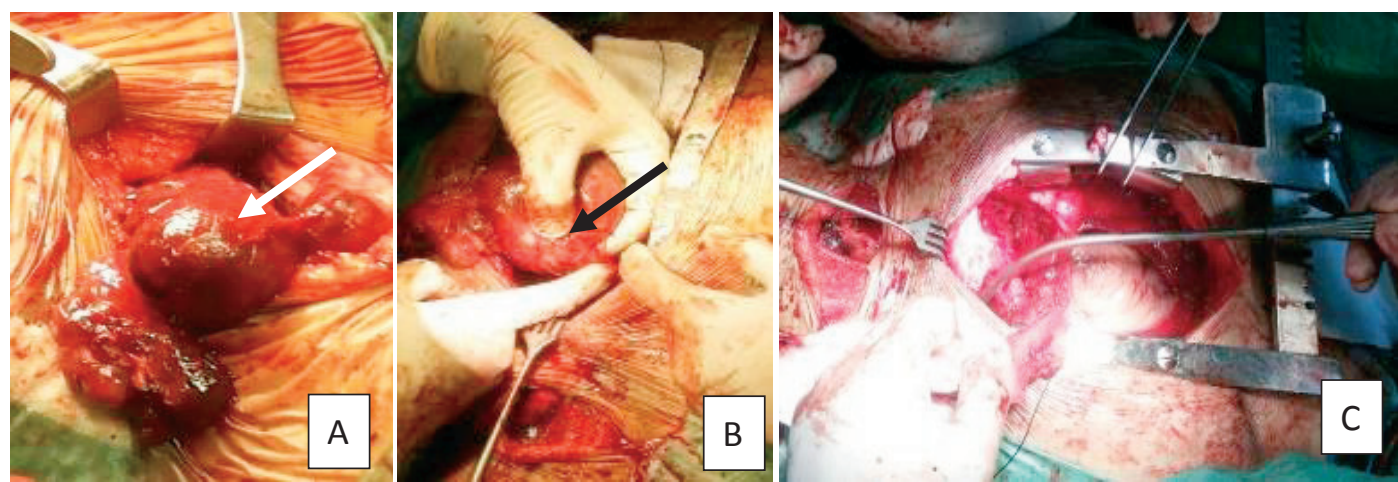

Gambar 4. A. Tiroid kanan terlihat lebih besar (panah putih) B. Kelenjar tiroid intratoraks (panah hitam) C. Rongga toraks setelah dilakukan total thyroidectomy. 


\section{DISKUSI}

\section{Goiter}

Struktur normal kelenjar tiroid terdiri atas kelenjar yang homogen, tetapi sering terbentuk nodul di antara struktur homogen tersebut. Nodul tersebut tumbuh secara lokal dan menyatu membentuk folikel, adenoma atau kista. Goiter adalah nodul tiroid yang membesar dua kali atau lebih dari ukuran normal. Nodul tiroid yang membesar dengan ukuran lebih dari $1 \mathrm{~cm}$ secara klinis dapat teraba pada pemeriksaan fisik, sedangkan nodul dengan ukuran kurang dari $1 \mathrm{~cm}$ sering tidak teraba. ${ }^{1,5}$

Insidens goiter diffuse dan nodular sangat tergantung pada status intake yodium pada suatu populasi. Pada area defisiensi yodium insidens goiter sangat tinggi dengan bentuk multinodular. Angka kejadian goiter pada wanita lebih tinggi dibanding laki-laki (13:1). Angka kejadian goiter meningkat pada wanita diatas 45 tahun. Penyebab goiter secara komprehensif dapat dilihat pada tabel 1 .

Tabel 1. Penyebab Goiter. ${ }^{6}$

\begin{tabular}{l}
\hline Faktor yang mempengaruhi multinodular goiter \\
\hline Faktor Primer \\
Faktor genetik yang berhubungan dengan kualitas replikasi \\
sel epitel \\
Abnormalitas struktur dan fungsi kelenjar tiroid \\
\hline Faktor sekunder \\
Peningkatan TSH (yang dipengarui oleh defisiensi yodium, \\
natural goitrogens, inborn errors of thyroid hormone \\
synthesis) \\
Merokok, stres,obat-obatan \\
Other thyroid-stimulating factors (IGF-1 and others) \\
Faktor endogen (gender)
\end{tabular}

Pada kasus ini, penderita tinggal di pulau Sumbawa provinsi Nusa Tengara Barat yang merupakan provinsi dengan cakupan garam yang mengandung cukup yodium paling rendah di antara 30 propinsi di Indonesia yakni 27,9\%. Cakupan garam masyarakat Nusa Tenggara Barat mengonsumsi garam beryodium tidak sesuai dengan kandungan yodium yang ditentukan WHO untuk mencapai Universal SaltIodization masyarakat. Syarat tercapainya Universal SaltIodization paling sedikit 90\% rumah tangga telah menggunakan garam beryodium yang mempunyai kadar antara 30-80 ppm. ${ }^{8}$

Kekurangan konsumsi yodium merupakan salah satu faktor yang menyebabkan penderita mengalami perbesaran kelenjar tiroid. Faktor risiko lain adalah penderita berjenis kelamin perempuan di mana insidens goiter lebih tinggi 13 kali pada perempuan dibanding pria. Usia penderita 50 tahun juga merupakan faktor risiko mengalami goiter, penelitian menyebutkan angka kejadian goiter meningkat pada bahwa usia diatas 45 tahun.

Perbesaran kelenjar tiroid pada pasien ini akibat kekurangan yodium bersifat multinodular. Pada palpasi teraba di sebelah kanan karena ukurannya $\pm 2 \mathrm{~cm}$, literatur menyebutkan bahwa perbesaran kelenjar tiroid akan teraba apabila ukurannya melebihi $1 \mathrm{~cm}$.

\section{Retrosternal goiter}

Retrosternal goiter adalah masuknya kelenjar tiroid 50\% atau lebih ke dalam rongga toraks. Banyak istilah yang dipakai untuk menggambarkan masuknya kelenjar tiroid ke rongga toraks di antaranya: substernal goiter, intratoraks goiter, retrosternal goiter dan mediastinal goiter. ${ }^{1,2,3}$

Kelenjar tiroid adalah kelenjar endokrin yang pertama kali tampak pada fetus, kelenjar ini berkembang sejak minggu ke-3 sampai minggu ke-4 dan berasal dari penebalan entoderm dasar faring, yang kemudian akan berkembang memanjang ke kaudal dan disebut divertikulum tiroid. Akibat bertambah panjangnya embrio dan pertumbuhan lidah maka divertikulum ini akan mengalami desensus sehingga berada di bagian depan leher dan bakal faring. Divertikulum ini dihubungkan dengan lidah oleh suatu aluran yang sempit yaituduktus tiroglosus yang muaranya pada lidah yaitu foramen cecum.Divertikulum ini berkembang cepat membentuk 2 lobus yang tumbuh ke lateral sehingga terbentuk kelenjar tiroid terdiri dari 2 lobus lateralis dengan bagian tengahnya disebutistmus. Pada minggu ke-7 perkembangan embrional kelenjar tiroidini mencapai posisinya yang terakhir pada ventral dari trakea yaitu setinggi vertebra servikalis V, VI, VII dan vertebra torakalis I, dan secara bersamaan duktus tiroglosus akan hilang. Perkembangan selanjutnya tiroid bergabung dengan jaringanultimobranchial body yang berasal dari branchial pouch V, dan membentuk C-cell atau sel parafolikuler dari kelenjar tiroid. Sekitar 75\% pada kelenjar tiroid ditemukan lobus piramidalis yang menonjol dari istmus ke kranial, ini merupakan sisa dari duktus tiroglosus bagian kaudal. Pada akhir minggu ke 7-10 kelenjar tiroid sudah mulai berfungsi, folikel pertama akan terisi koloid. Sejak saat itu fetus mulai mensekresikanThyrotropin Stimulating Hormone (TSH) dan sel parafolikuler pada fetus sementara belum aktif.,

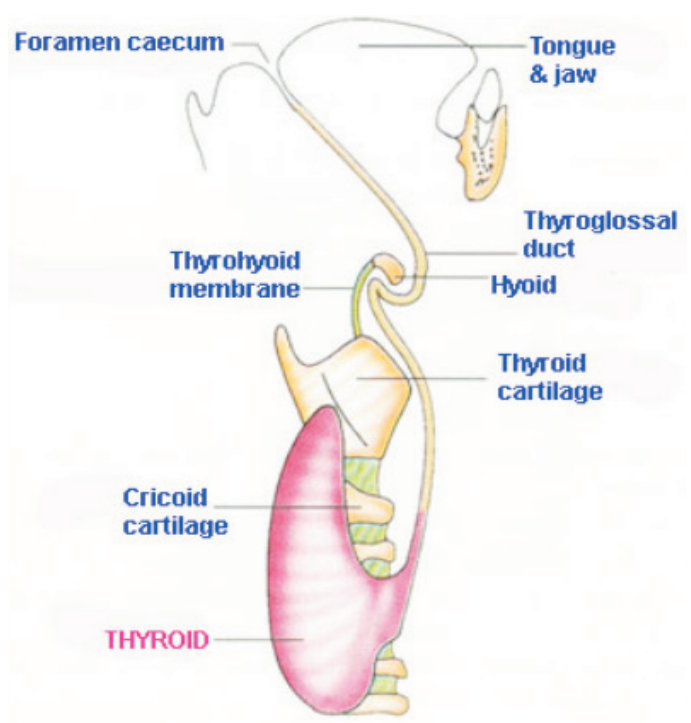

Gambar 6. Embriologi kelenjar tiroid. ${ }^{7}$ 


\section{Klasifikasi retrosternal goiter \\ Retrosternal goiter primer}

Retrosternal goiter diklasifikasikan menjadi primer dan sekunder. Retrosternal goiter primer disebut juga abberant, terjadi hanya sekitar $1 \%$ dari seluruh retrotsernal goiter. Terbentuk dari kelenjar tiroid aksesorius (ektopik) yang berada di rongga dada. Retrosternal goiter primer tidak ada hubungan dengan kelenjar tiroid dileher dan tidak menerima suplai darah dari leher. ${ }^{9}$

Pada beberapa individuembriologycal origin kelenjar tiroid dapat menetap sampai usia dewasa tergantung kelainan pada proses embriologi. Berikut adalah anatomi dan patologi ektopik tiroid: ${ }^{11,12,13}$ (1) Foramen Caecum; pada orang dewasa sisa foramen caecum dapat dilihat pada persambungan antara $2 / 3$ anterior dan $1 / 3$ posterior lidah, (2) Lingual thyroid; Pada saat kelenjar tiroid gagal migrasi ke leher, akan meninggalkan benjolan kelenjar tiroid pada bagian belakang lidah, (3) Kista thyroglossal; selama proses embriologi, kelenjar tiroid masih terhubung dengan lidah melalui duktus thyroglossal. Kemudian duktus ini mengeras dan akan menghilang. Jika proses ini gagal maka akan bermanifestasi sebagai kista thyrogolssal. Kista ini terletak pada tulang hyoid atau tepat dibawahnya, (4) Lobus pyramidal; Pyramidal tiroid dijumpai lebih dari 50\% pasien dengan tiroid ektopik. Struktur ini terbentuk sebagai akibat kegagalan obliterasi duktus thyroglossal bagian inferior. ukurannya bervariasi dan ditemukan menempel pada bagian atas isthmus tiroid atau pada perbatasan antara kedua kelenjar tiroid, (5) Ectopic tiroid rest; Tiroid rest adalah sisa endapan dari kelenjar tiroid, biasanya ditemukan pada area thyrothymic di bawah kelenjar tiroid.

\section{Retrosternal Goiter Sekunder}

Retrosternal goiter sekunder merupakan kasus terbanyak dari retrosternal goiter. Kelenjar goiter turun ke bagian bawah leher menuju rongga toraks sehingga terdapat hubungan antara kelenjar tiroid di leher dengan kelenjar tiroid di rongga toraks. Suplai pembuluh darah dari arteri tiroid anterior dan posterior. Migrasi kelenjar

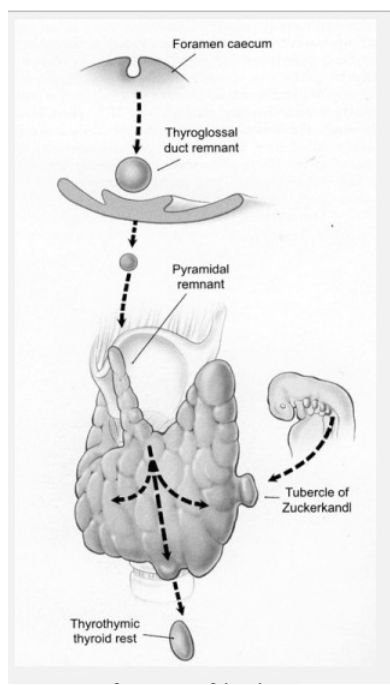

Gambar 7. Proses embriologi terbentuknya kelenjar tiroid ektopik. $^{7}$ tiroid ke rongga toraks dipengaruhi berbagai faktor seperti bertambah beratnya kelenjar tiroid, tekanan negatif intratoraks, pergerakan napas, proses menelan dan bentuk leher yang pendek dan ditambah lagi tidak adanya struktur anatomi sebagai penghalang antara leher bawah dengan thoracic inlet. ${ }^{8}$

Retrostenal goiter sekunder berbeda dengan retrosternal goiter primer (ektopik tiroid). Retrosternal goiter primer harus memenuhi syarat-syarat sebagai berikut:9,11,13 (1) Suplai darah terpisah (independent), (2) Kelenjer tiroid leher normal, (3) Proses patologis berbeda antara kelenjar tiroid leher dan kelenjar tiroid ektopik, dan (4) Tidak ada riwayat keganasan kelenjar tiroid sebelumnya.

Retrosternal goiter 75-90\% berlokasi dimediastinum anterior, sekitar 10-15\% terletak dimediastinum posterior. Retrosternal goiter biasanya migrasi ke sisi kanan toraks karena resistensi sedikit dan jauh dari arcus aorta dan cabang-cabangnya.

Massa pada mediastinum anterior biasanya berupa thymoma, lymfoma, germ cell tumor, pheochromacytoma, neurogenic tumor dan mesenchymal tumor. Retrosternal goiter yang berada di mediastinum anterior sering salah diagnosa dengan kelainan di atas. ${ }^{11}$

Pada kasus ini kelenjar tiroid masuk lebih dari 50\% ke rongga toraks sehingga pada foto toraks terlihat seperti kelenjar ektopik tiroid di rongga toraks yang tidak ada hubungannya dengan kelenjar tiroid cervical. Pada pemeriksaan CT scan ternyata terdapat hubungan antara kelenjar tiroid dirongga toraks dengan kelenjar tiroid kanan, terlebih lagi saat dilakukan thyroidectomy terbukti ada hubungan antara kelenjar tiroid servikal kanan dengan kelenjar tiroid di rongga dada. Kelenjar tiroid retrosternal berkapsul, tidak ada hubungan dengan struktur mediastinum, pembuluh darah berasal dari servical. Berdasarkan data yang didapatkan perioperatif, pasien ini memenuhi kriteria sebagai retrosternal goiter sekunder bukan ektopik tiroid.

Migrasi kelenjar tiroid ke rongga toraks dipengaruhi berbagai faktor seperti bertambah beratnya kelenjar tiroid, tekanan negatif intratoraks, pergerakan napas, proses menelan dan bentuk leher yang pendek dan ditambah lagi tidak adanya struktur anatomi sebagai penghalang antara leher bawah dengan thoracic inlet. Pada pasien ini bentuk leher pendek sehingga mempunyai faktor predisposisi terjadinya retrosternal goiter.

\section{Prevalensi}

Insidens retrosternal goiter pada kasus thyroidectomy berkisar $1,7-21 \%$. Variasi insedens ini karena adanya perbedaan definisi retrosternal goiter pada berbagai senter, perbedaan geografi, populasi pasien dan pola rujukan. Kebanyakan retrosternal goiter terjadi pada usia 50 tahun, tetapi pernah dilaporkan terjadi pada usia termuda 15 tahun dan tertua 19 tahun. Perbandingan terjadinya retrosternal goiter antara wanita dan pria 4:1. Insidens keganasan pada beberapa studi dilaporkan sekitar 2,5\% sampai $21 \%$. Pasien retrosternal goiter $40-50 \%$ asimptomatik. ${ }^{11}$ 
Tabel 2. Proses embriologi kelenjar tiroid dan ektopik tiroid. ${ }^{13}$

\begin{tabular}{|c|c|c|c|}
\hline Lokasi & Gejala & Usia & Status tiroid \\
\hline Lingual & $\begin{array}{l}\text { Disfagia, disfonia,batuk, sensasi benda asing, mendengkur, } \\
\text { obstruktif sleep apnea dan perdarahan, kadang-kadang } \\
\text { asimptomatik }\end{array}$ & 40 tahun & $\begin{array}{l}\text { Biasanya hipotrioid, } \\
\text { sebagian kecil eutiroid }\end{array}$ \\
\hline Submandibular & Teraba pada saat palpasi,mobile, massa yang tidak nyeri. & 4-81 & Eutiroid \\
\hline Ductus thyroglossal & Asimptomatik & $4-75$ & $\begin{array}{l}\text { Hipotiroid atau } \\
\text { eutiroid }\end{array}$ \\
\hline Intratracheal & Dipsnue, batuk, sulit menelan, batuk darah dan stridor & $30-50$ & Eutiroid \\
\hline $\begin{array}{l}\text { Intrathoracal (mediastinum, } \\
\text { paru, jantung) }\end{array}$ & Batuk kering, dipsnue, batuk darah Asimptomatik & $40-77$ & Eutiroid \\
\hline Struma ovarii & $\begin{array}{l}\text { Biasanya asimptomatik, nyeri abdomen bagian bawah, massa } \\
\text { abdominal, perdarahan vagina abnormal. }\end{array}$ & 45 & $\begin{array}{c}\text { Eutiroid } \\
\text { Hipertiroid 5-15\% }\end{array}$ \\
\hline Kelenjar adrenal & Asimptomatik (incidental finding) & $50-60$ & Eutiroid \\
\hline Duodenum dan pancreas & $\begin{array}{l}\text { Asimptomatik (incidental finding) } \\
\text { Nyeri abdomen }\end{array}$ & $50-63$ & Eutiroid \\
\hline $\begin{array}{l}\text { Dual ectopy (biasanya } \\
\text { lingual dan subhyoid) }\end{array}$ & Asimptomatik Midline neck swelling & 18 & $\begin{array}{l}\text { Etiroid atau } \\
\text { Hipotiroid }\end{array}$ \\
\hline
\end{tabular}

Tabel 3. Klasifikasi retrosternal goiter sekunder. ${ }^{14}$

\begin{tabular}{|c|c|c|c|c|}
\hline \multicolumn{2}{|r|}{ Lokasi } & \multirow{2}{*}{$\begin{array}{c}\text { Anatomi } \\
\text { Anterior dari pembuluh darah besar, } \\
\text { trakhea dan RLN }\end{array}$} & \multirow{2}{*}{$\begin{array}{c}\text { Prevalensi } \\
85 \%\end{array}$} & \multirow{2}{*}{$\begin{array}{c}\text { Tipe Pembedahan } \\
\text { Transcervical (sternotomy jika diameter } \\
\text { intratoraks goiter }>\text { diameter thoracic inlet }\end{array}$} \\
\hline I & Anterior mediastinum & & & \\
\hline II & Posterior mediastinum & $\begin{array}{l}\text { Posterior dari pembuluh darah besar, } \\
\text { trakhea dan RLN }\end{array}$ & $15 \%$ & $\begin{array}{l}\text { Transcervical (sternotomy jika diameter } \\
\text { intratoraks goiter }>\text { diameter thoracic inlet } \\
\text { Sternotomy atau posterolateral thoracotomy } \\
\text { jika tipe IIB }\end{array}$ \\
\hline IIA & Ipsilateral extension & & & \\
\hline IIB & Contralateral extension & & & \\
\hline B1 & $\begin{array}{l}\text { Extention posterior ke } \\
\text { trakea dan esofagus }\end{array}$ & & & \\
\hline B2 & $\begin{array}{l}\text { Extension antara trakea } \\
\text { dan esofagus }\end{array}$ & & & \\
\hline III & $\begin{array}{l}\text { Isolated mediastinal } \\
\text { goiter }\end{array}$ & $\begin{array}{l}\text { Tidak ada hubungan dengan } \\
\text { cevical tiroid, suplai darah dari } \\
\text { mediastinum }\end{array}$ & $1 \%$ & Transcevical atau sternotomy \\
\hline
\end{tabular}

Retrosternal goiter kebanyakan jinak, insidens keganasan sekitar $23 \%$. insidens keganasan retrosternal goiter lebih kecil dibandingkan servical goiter. Faktor risiko keganasan pada retrosternal goiter diantaranya riwayat keluarga dengan kelainan kelenjar tiroid, pernah radiasi daerah servical, rekurens goiter dan adenopathy goiter. Sistematik review menunjukkan 5-10\% operasi retrosternal goiter dilakukan pada kasus rekurans atau persistent. ${ }^{11,15}$

Pada kasus ini, penderita seorang wanita dengan usia 56 tahun, dengan hasil histopatologi kelenjar tiroid jinak. Penderita tidak pernah mengalami pembesaran kelenjar tiroid sebelumnya, tidak ada riwayat keganasan. Riwayat keluarga yang menderita kelainan serupa tidak ada.

\section{Gejala klinis}

Gejala klinis retrosternal bervariasi tergantung pada tekanan pada jalan napas, esofagus, pembuluh darah, sistem saraf atau gabungan dari beberapa kelainan di atas. Gejala yang paling sering dijumpai adalah massa pada sevikal (65\%), disfagia (36\%), dispsnue (32\%) dan gejala tambahan lain seperti batuk, stridor,wheezing dan suara parau. Kelumpuhan nervus laryngeal ditemukan pada $61 \%$ kasus. Perburukan sistem pernapasan biasanya dicetuskan oleh infeksi saluran napas, perdarahan akut pada nodul goiter, posisi goiter pada mediastinum atau kombinasi dari kelainan di atas. ${ }^{11,13,115,16,17}$

Sindrom Horner (miosis, anhidrosis dan ptosis) merupakan manisfestasi kelainan neurologis akibat retrosternal goiter tetapi insidensinya kecil. Pemberton sign adalah salah satu tanda adanya retrosternal goiter. Pemberton pada tahun 1921 pertama kali memperkenalkan manuver ini. Kedua tangan diangkat ke atas, apabila ada retrosetrnal goiter maka setelah beberapa menit akan terlihat gejala kongesti yaitu wajah menjadi merah, dispnea, stridor. Gejala klinis tersebut muncul karena peningkatan tekanan pada thoracic inlet dan kegagalan venus return pada kepala dan leher. ${ }^{18,19,20}$ 
Toksik nodular goiter adalah komplikasi yang umum terjadi pada kasus non toksis nodular goiter, sering di jumpai pada pasien usia lebih dari 50 tahun yang sebelumnya telah mengalami non toksik nodular goiter dalam waktu yang lama. Tidak ada laporan spesifik insidens tirotoksikosis pada retrosternal goiter. ${ }^{11,21}$

Benign retrosternal goiter pertumbuhannya lambat, apabila masa mencapai ukuran yang besar dapat menyebabkan penekanan pada trakea, oesophagus, pembuluh darah dan sistem saraf yang menyebabkan timbulnya gejala seperti dipsneu, stridor, disfagia, vena cava superior sindrom, deep vein thrombosis pada vena subclavia, disfonia dan sindrom horner. Tetapi pada beberapa kasus tidak menimbulkan gejala. Keparahan gejala tergantung derajat kompresi. Gejala kompresi retrosternal goiter lebih berat dibandingkan servikal goiter karena keterbatasan thoracic inlet dan rongga toraks. Sumbatan jalan napas yang ditandai dengan stridor dapat mengancam jiwa. Hal tersebut dapat dipicu oleh perdarahan intragoiter oleh karena trauma/spontan, atau infeksi trakea. Retrosternal goiter pada umumnya eutiroid, tetapi dapat ada juga yang menunjukkan gejala hipertiroid dan tirotoksikosis tetapi jarang sekali hipotiroid. ${ }^{10,14,15}$

Pada kasus ini gejala klinis yang dominan pada pasien adalah nyeri dada, sesak napas hanya bila beraktivitas berat. Nyeri dada pada penderita karena massa tiroid yang besar menyebabkan kompresi pada sistem saraf. walaupun terjadi gangguan pada sistem saraf tetapi tidak terjadi manifestasi neurologis seperti sindrom horner (miosis, anhidrosis dan ptosis) karena letak massa di mediastinum anterior dan pertumbuhan massa ke bawah sehingga pendesakan kearah posterior. Pada pasien ini terjadi pendesakan jalan napas ke posterior terutama setinggi carina menyebabkan gejala sesak napas terutama muncul saat aktifitas berat.

Gejala vena cava superior sindrom tidak ditemukan pada pasien ini karena massa tidak mendesak vena cava superior hanya menyebabkan pendesakan arcus aorta ke arah caudal. Tidak dijumpai gangguan menelan atau pun suara parau, pada pemeriksaan fisik tidak ditemukan stridor ataupun wheezing.

Pasien dengan status eutiroid, pada pemeriksaan fungsi tiroid didapatkan kadan FT3, FT4 dan TSH dalam batas normal. Tidak ditemukan tanda dan gejala hipotiroid atau pun hipertiroid. Hal ini sesuai dengan hasil beberapa penelitian yang menyatakan bahwa sebagian besar pasien retrosternal goiter memiliki status tiroid yang normal.

Tabel 4. Gejala utama retrosternal goiter. ${ }^{18}$

\begin{tabular}{ll}
\hline \multicolumn{1}{c}{ Gejala } & Persentase \\
\hline Distres pernapasan & $37(28,0)$ \\
Gangguan menelan & $23(17,4)$ \\
Masalah kosmetik & $11(8,3)$ \\
Kekhawatiran akan keganasan & $4(3,0)$ \\
Asimptomatik & $57(43,2)$ \\
\hline
\end{tabular}

Tidak ditemukan gejala klinis yang mengarah pada keganasan seperti penurunan berat badan yang drastis dalam waktu singkat, penurunan berat badan dan gejala metastase. Gejala utama pasien adalah nyeri dada.

Keunikan pada pasien ini adalah pada inspeksi tidak terlihat adanya perbesaran kelenjar tiroid leher, sehingga adanya massa tiroid dimediastinum bukan merupakan pemikiran utama. Massa pada mediastinum yang di temukan pada ronten toraks awalnya di diduga sebagai tumor mediastinum dan aneurisma aorta.

\section{Diagnosis Retrosternal goiter}

Diagnosis retrosternal goiter berdasarkan gejala klinis, pemeriksaan fisik dan pemeriksaan penunjang. Pemeriksaan penunjang yang dapat dilakukan adalah foto toraks, USG, CT scan dan MRI. CT scan adalah gold standar pemeriksaan pre operatif. Retrospektif studi Grainger et al. menunjukkan 27 pasien yang menjalankan operasi retrosternal goiter 34 dari mereka telah melakukan CT scan sebelum operasi. ${ }^{1}$ CT scan merupakan pemeriksaan imaging yang paling baik untuk menentukan ekstensi retrosternal goiter, hubungannya dengan organ mediastinum, visualisasi distorsi seperti pergeseran trakhea dan menilai kompresi pada organ sekitarnya. Pada CT scan, retrosternal goiter terlihat sebagai masa yang berbatas tegas dengan densitas bervariasi tergantung pada kadar yodiumnya. Apabila kandungan yodium rendah densitas menyerupai soft tissue. Apabila kandungan yodium tinggi densitas lebih tinggi dari soft tissue. Densitas biasanya tidak merata tergantung pada kista koloid dan plaque kalsifikasi. ${ }^{2}$ Pemeriksaan CT scan toraks sangat membantu rencana tindakan selanjutnya seperti intubasi atau operasi. MRI adalah pemeriksaan tambahan yang tidak rutin dilakukan tetapi berguna untuk visualisasi jaringan dan menilai invasi lokal struktur vaskular oleh tumor. ${ }^{11,17}$

Tes fungsi tiroid berguna untuk menilai fungsi kelenjar tiroid. Pemeriksaan fungsi paru berfungsi untuk menilai derajat obstruksi dan sebagai data dasar untuk menilai perbaikan fungsi paru setelah operasi thyroidectomy. Biopsi retrosternal goiter tidak dianjurkan karena dapat menyebabkan perdarahan yang dapat memperburuk obstruksi saluran napas dan respiratory distress. ${ }^{11,15.16}$

Transesophageal echocardiography (TEE) direkomendasikan pada lesi mediastinal paracardial karena TEE dapat menampilkan data anatomi yang lebih baik. TEE relevans sebagai pemeriksaan pada posterior mediastinal goiter jika dicurigai sebagai lesi invasif. ${ }^{17,20}$

Fine needle aspiration biopsy (FNAB) kurang baik sebagai diagnosis histopatologi nodultiroid, begitu juga sebagai diagnosis histopatologi retrosternal goiter. Keakuratan FNAB sebagai diagnosis histologi retrosternal goiter rendah karena heterogenisitas nodul tiroid dan lesi yang sulit dijangkau. Retrosternal goiter $80 \%$ jinak, sebagain besar diagnosis histopatologinya multinodular goiter (51-80\%) dan sebagian kecil follicular adenoma (40\%). Keganasan retrosternal goiter histopatologinya 
follicular carsinoma sekitar $4,5 \%$ dan papillary carsinoma $2,5-6,6 \% .19,22$

Selain tes fungsi tiroid, USG dan CT scan, ada pemeriksaan lain yang digunakan untuk investigasi kelainan kelenjar tiroid yaitu radioisotope scan. Laporan kasus Mahajan tahun 2012 menggunakan Technetium-99m $(99 \mathrm{mTc})$ pertechnetate radioisotope tiroid scan berhasil mendiagnosis retrosternal goiter yang tidak terdeteksi pada USG leher pada pasien asimptomatik. Sensitivitas USG lebih rendah jika dibandingkan dengan CT scan. ${ }^{23}$

Diagnosis pada kasus ini sulit, terbukti dengan berbagai pemeriksaan didapatkan kesimpulan diagnosa yang berbeda-beda. Awalnya pasien dilakukan pemeriksaan foto toraks dengan kesimpulan suspek massa mediastinum diagnosis banding: aneurisma aorta, disarankan CT scan dengan kontras. Kemudian dilakukan CT scan dengan kontras, hasilnya ditemukan massa mediastinum superior anterior ukuran $\pm 8 \mathrm{~cm} \times 6 \mathrm{~cm} \times 17 \mathrm{~cm}$ kesan dari tiroid kanan diagnosis banding: abses paratrakhea, menyempitkan airway terutama setinggi carina. Aneurisma aorta tidak ditemukan pada CT scan yang sebelumnya disebutkan pada foto toraks.

Pada pemeriksaan CT scan toraks mulai didapatkan diagnosa yang mengarah ke perbesaran kelenjar tiroid di rongga toraks. Dari CT scan juga dapat dilihat adanya pendesakan dan penyempitan airway, serta terlihat mendesak arcus aorta ke caudal, terlihat kalsifikasi, dan terlihat hubungannya dengan tiroid dekstra.

Pemeriksaan selanjutnya yaitu FNAB CT guiding toraks. Hasil pemeriksaan FNAB CT guiding toraks dengan kesimpulan mengesankan papillary carsinoma tiroid retrosternal. Selanjutnya pasien direncanakan operasi thyroidectomy + sternotomy karena massa tiroid yang besar dan mengesankan keganasan.

Hasil pemeriksaan histopatologi jaringan setelah operasi menunjukkan tumor tidak menembus kapsul. Tidak tampak proses spesifik ataupun tanda-tanda keganasan dengan kesimpulan follicular edenoma disertai adenomatous goiter. Sehingga diagnosa akhir pasien ini adalah retrosternal goiter.

Hal perlu menjadi perhatian dalam diagnosis kasus ini adalah setiap perbesaran mediastinum selain dipikirkan ke arah tumor mediastinum jangan lupa dipikirkan kearah perbesaran kelenjar tiroid retrosternal baik yang primer (ektopik tiroid) maupun sekunder. Sehingga pemikiran secara komprehensif sangat diperlukan dalam mendiagnosis pasien.

\section{Penatalaksanaan}

Indikasi operasi pada retrosternal goiter adalah kecurigaan kearah keganasan, kompresi trakeo-esofageal dan alasan kosmetik. Gejala kompresi adalah indikasi reseksi pada servikal goiter maupun retrosternal goiter. Pada retrosternal goiter walaupun asimptomatik, reseksi merupakan suatu indikasi karena tidak ada terapi medis yang efektif untuk mencegah pertumbuhan kelenjar tiroid. ${ }^{11,24,25}$
Terapi pembedahan merupakan indikasi pada semua pasien dengan retrosternal goiter, kecuali pasien dengan risiko tinggi tindakan pembedahan. Tindakan lebih awal dan agresif diperlukan pada pasien yang menunjukkan gejala kompresi trakea. Acute airways distress memerlukan tindakan intubasi atau pembedahan semi-emergensi. Pada pasien asimptomatik, terapi pembedahan berguna untuk mencegah terjadinya situasi yang dapat mengancam jiwa seperti acute airways compression dan mencegah risiko thyroid malignancy. Berikut adalah beberapa alasan melakukan tindakan bedah antara lain adalah: ${ }^{25}$ (1) terapi non bedah retrosternal goiter seperti hormon dan yodium radioaktif angka keberhasilannya sangat kecil, dan (2) keadaan yang mengancam jiwa seperti perbesaran kelenjar yang sangat cepat, perdarahan tiroid dan perubahannya menjadi ganas.

Pembedahan retrosternal goiter kebanyakan melalui insisi servical, tetapi sternotomy atau thorakotomy kadang diperlukan pada kondisi khusus. Insisi servical tingkat morbiditasnya lebih rendah jika dibandingkan sternotomy atau thorakotomy. Tetapi insisi servical meningkatkan risiko perdarahan, kerusakan nervus laryngeal recurrent dan incomplete removal goiter. ${ }^{26.27,28}$

Huins et al. tahun 2008 membuat klasifikasi baru teknik pembedahan pada retrosernal goiter. Teknik tersebut meliputi insisi servikal, manubriotomy dan full sternotomy. Klasifikasi teknik pembedahan ini berdasarkan lokasi anatomi dari goiter di dalam rongga toraks. ${ }^{1}$

Retrosternal goiter umumnya menerima aliran darah dari pembuluh darah servikal tiroid, tetapi pada "primary intrathoracic goiter" menerima aliran darah dari intratoraks memerlukan teknik pembedahan sternotomy. Pada posterior mediastinal goiter memerlukan teknik pembedahan kombinasi cervical-thorakal atau cervicalsternotomy. ${ }^{27,28}$

Indikasi pembedahan pada kasus ini adalah massa yang besar menyebabkan kompresi ke organ sekitarnya sehingga menimbulkan gejala klinis nyeri dada dan sesak saat aktivitas. Di samping itu pada pemeriksaan FNAB CT guiding toraks mengesankan suatu keganasan sehingga diputuskan untuk operasi secepatnya.

Teknik opersi pada kasus ini adalah sternotomy, teknik ini dipilih karena massa tiroid yang besar melebihi diameter thoracic inlet sehingga dengan insisi servikal tidak dapat mengeluarkan massa tiroid. Walaupun menurut teori letak tiroid dimediastinum anterior, terletak dianterior dari pembuluh darah besar, trakhea dan nervus nervus laryngeal recurrent teknik operasi cukup dengan insisi servikal. Pada kondisi khusus seperti kasus ini maka pendekan teknik operasi yang tepat adalah sternotomy.

\section{Komplikasi}

Komplikasi post-operasi meliputi cedera pada nervus laryngeus recurrent, komplikasi pada jalan napas, hematom,hipotiroidism dan hipokalsium. Komplikasi lain yang dapat terjadi seperti pneumotoraks, pneumonia, efusi pleura dan cervical plexus neurophaty. Insidens komplikasi 
Tabel 5. Klasifikasi dan teknik pembedahan retrosternal goiter $^{1}$

\begin{tabular}{cll}
\hline Derajat & \multicolumn{1}{c}{ Lokasi anatomi } & \multicolumn{1}{c}{$\begin{array}{c}\text { Teknik } \\
\text { pembedahan }\end{array}$} \\
\hline 1 & Di atas arcus aorta & Cervical \\
2 & Pada arcus aorta sampai & Manubriotomy \\
& pericardium & Full sternotomy \\
\hline
\end{tabular}

bervariasi pada berbagai senter. Cedera nervus laryngeous reccurent berkisar 2,7\% sampai 5,1\%. Angka kejadian kelumpuhan nervus laryngeal recurrent yang bersifat sementara dilaporkan sekitar 0-7\% dan kelumpuhan nervus laryngeal recurrent yang permanen sekitar $0-11 \%$. Insidens transient hypocalemia berkisar antara $3,4 \%$ sampai $13,3 \% .^{28,29}$

Komplikasi operasi retrosternal goiter pada jalan napas sekitar $12 \%$. Pasien yang mengalami komplikasi pada jalan napas kebanyakan adalah pasien usia tua, goiter yang besar dan telah terjadi kompresi trakea sebelum operasi dilaksanakan. ${ }^{11}$

Penelitian Landerholm tahun 2014 menyimpulkan dari 132 pasien yang menjalani tindakan operasi thyroidectomy terdapat beberapa komplikasi dari ringan sampai berat. Komplikasi tersebut dapat dilihat pada tabel 6.

Pada kasus ini tidak terjadi komplikasi post operasi pada pasien ini baik perdarahan, infeksi, cedera pada nervus laryngeus recurrent, komplikasi pada jalan napas, hematom, hipotiroidism, pneumotoraks, pneumonia, efusi pleura dan cervical plexus neurophaty. Tidak ada komplikasi post operasi pada kasus ini karena tiroid retrosternal terletak di mediastinum anterior sehingga struktur penting seperti pembuluh darah besar, nervus laryngeus recurrent terletak di bawah massa tiroid. Ditambah lagi massa tiroid yang berkapsul dan tidak melekat erat pada struktur disekitarnya, sehingga saat dilakukan pengangkatan massa tiroid tidak menyebabkan banyak kerusakan pada organ sekitarnya.

\section{KESIMPULAN}

Telah dilaporkan kasus seorang penderita berusia 56 tahun, datang ke RSUD Dr. Soetomo dengan keluhan nyeri dada. Pada foto toraks tampak gambaran massa mediastinum. CT scan toraks dengan kontras dengan hasil ditemukan massa mediastinum superior anterior ukuran $\pm 8 \mathrm{~cm} \times 6 \mathrm{~cm} \times 17 \mathrm{~cm}$ kesan dari tiroid kanan, diagnosis banding: abses paratrakhea, menyempitkan airway terutama setinggi carina. Hasil pemeriksaan FNAB CT guiding toraks dengan kesimpulan mengesankan papillary carsinoma tiroid retrosternal. Selanjutnya pasien dilakukan operasi thyroidectomy + sternotomy. Hasil pemeriksaan Histopatologi jaringan setelah operasi menunjukkan follicular edenoma disertai adenomatous goiter. Sehingga diagnosa akhir pasien ini adalah retrosternal goiter. Hal perlu menjadi perhatian dalam diagnosis kasus ini adalah setiap perbesaran mediastinum selain dipikirkan kearah tumor mediastinum jangan lupa dipikirkan ke arah perbesaran kelenjar tiroid retrosternal. Tidak ada komplikasi post-operasi pada pasien ini. Selama rawat jalan penderita hanya mengalami keluhan ringan berupa nyeri dada bekas tempat operasi. Satu minggu kemudian penderita pulang ke pulau Sumbawa Nusa Tenggara Barat dan melanjutkan pengobatan rawat jalan di Sumbawa.

\section{DAFTAR PUSTAKA}

1. Huins C, Georgalas C, Mehrzad H, Tolley NS. A new classification system for retrosternal goitre based on a systematic review of its complications and management. Int J Surg. 2008; 6: 71-76.

2. Chen X, Xu H, Ni Y,Sun K, Li W. Complete excision of a giant tiroid goiter in posterior mediastinum. J Cardiothorac Surg. 2013; 8: 207.

3. Tsakiridis K, Visouli AN, Zarogoulidis P, et al. Resection of a giant bilateral retrovascular intrathoracic goiter causing severe upper airway obstruction, 2 years after subtotal thyroidectomy: a case report and review of the literatur. J Thorac Dis. 2012; 4: 41-48.

4. Madjar S, Weissberg D. Retrostenal goiter. Chest. 1995; 108: 78-82.

5. Gharib H, Papini E, Paschke R, et al. American association of clinical endocrinologists, associatione medicine endocrinology, and European thyroid association medical guidelines for clinical practice for the diagnosis and management of thyroid nodules. Endocr Pract. 2006; 12: 63-102.

6. Medeiros G. Multinodular goiter. 2013.(cited 2015 June 13). Available from http//www.thyroidmanager.org.

7. Fleming B. A comprehensive and up to date guide to endocrine surgery. 2010. (cited 2015 May 17). Available from http//www. Endocrinesurgery.net.au.

8. Departemen Kesehatan Republik Indonesia. Laporan hasil riset kesehatan dasar Indonesia (Riskesdas). Jakarta: Badan Litbangkes, Depkes RI. 2007.

Tabel 6. Komplikasi post-operasi retrosternal goiter ${ }^{18}$

\begin{tabular}{lccc}
\hline \multicolumn{1}{c}{} & $\begin{array}{c}\text { Gejala kompresi } \\
(\mathbf{n = 6 0 )}\end{array}$ & $\begin{array}{c}\text { Tanpa gejala kompresi } \\
(\mathbf{n}=\mathbf{7 2})\end{array}$ & Total pasien $(\%)$ \\
\hline Operasi ulang karena perdarahan & 1 & 2 & $3(2,3)$ \\
Temporary RLN palsy & 5 & 2 & $7(5,3)$ \\
Permanent RLN palsy & 1 & 1 & $2(3,8)$ \\
Permanent hypoparatiroidism & 1 & 1 & $3(2,3)$ \\
Meninggal & 2 & $10(13,9)$ & $20(15,2)$ \\
\hline Total komplikasi $(\%)$ & $10(16,7)$ & & \\
\hline
\end{tabular}


9. Alwan MH. The retrosternal (substernal) goiter. Basrah Journal of Surgery. 2010; 16.

10. Oueriachi FE, Hammoumi MM, Arsalane, E et al. Primary mediastinal goiters. SpringerPlus. 2014; 3: 503.

11. Wang J, Fang J. Ectopic thyroid mass in the left lateral neck and anterior mediastinum: a case report. J Med Cases. 2014; 8: 351.

12. Noussios G, Anagnostis G, Goulis DG, Lappas D, Natsis K. Ectopic thyroid tissue: anatomical, clinical, and surgical implications of rare entity. EurJ Endocrinol. 2011; 165: 375-382.

13. Ibrahim NA, Fadeyibi I. Ectopic Thyroid: etiology, pathology and management. Hormones. 2011; 10: 261-9.

14. Hussain Z.Substernal goiter classification. 2010. (cited 2015 May 17). Available from http://www.aarathyroidclinic.com.

15. Somakhvalo A, Loberant N, Makhoul N. Posterior mediastinal goiters: Report of two case and literature review. Respir Med Case Rep. 2012; 65-8

16. Irfan M, Jihan WS, Shahid H. Massive goiter with retrosternal encasing trachea and esophagus. Med J Malaysia. 2010; 65: 1.

17. Nun AB, Soudack M, Besst LA. Retrosternal thyroid goiter: 15 years experience. Imaj. 2006; 8.

18. Landerholm K, Jarhult J.Should asymptomatic retrosternal goiter be left untreated? a prospective single-center study. Scand J Surg. 2014; $1: 4$.

19. Kilic D, Findikcioglu A, Ekici Y, Alemdaroglu U, Hekimoglu $\mathrm{K}$.When is transthoracic approach indicated in retrosternal goiters? Ann Thorac Cardiovasc Surg. 2011.
20. Dempsey GA, Snell JA, Jones TM. Anaesthesia for massive retrosternal thyroidectomy in a tertiaty referral centre. Br J Anaesth. 2013; 51: 1-6.

21. Ahmed I, Farooq U, Afridi Z, Maryum A. An Experience with retrosternal goiter: analysis of 89 cases. Pak J Med Sci. 2010; 26 : 897-900.

22. Jaroszewski D, Bakaeen FG, Huh J. Acute respiratory distress secondary to posterior mediastinal goiter: a case report. Cases $J$. 2009; $2: 58$.

23. Mahajan MS, Negi DS, Sharma R. Incidental diagnosis of primary intrathoracic goiter on radionuclide $99 \mathrm{~m}$-tc pertechnetate radioisotope tiroid scan. Thyroid Research and Practice. 2012; 9: 3

24. Wheeler HM. The surgical management of retrosternal (intrathoracic) goiter. World Journal of Endocrine Surgery. 2013; 28-30.

25. Rugiu MG, Piemonte M. Surgical approach to retrosternal goitre:do we still need sternotomy? Acta Otorhinolaryngol Ital. 2009; 29 331-338.

26. Regal M, Zakaria HM, Ahmed AS et al. Substernal thyroid masses. Oman Med J. 2010; 25: 4.

27. Neves MC,Rosano M, Hojaij FC et al.Critical analysis of 33 pateint with substernal goiter surgically treated by neck incision. Braz J Otohinolaryngol. 2009; 75; 172-6.

28. Sakkary MA, Abdulrahman AM, Mostafa AM, Abbas AA, Zedan $\mathrm{MH}$. Retrosternal goiter: The need for approach based on CT finding: Surgeons view. J Egypt Natl Canc Inst. 2012; 25: 85-90.

29. Testini M, Gurrado A, Bellantone R, et al. Recurrent laryngeal nerve palsy and substernal goiter. An Italian multicenter study. J Visc Surg. 2014; 151: 183-9. 